\title{
Moradia e pertencimento: a defesa do Lugar de viver e morar por grupos sociais em processo de vulnerabilização
}

\author{
Housing and sense of belonging: the defense of the Place \\ of living by social groups undergoing vulnerability processes
}

Maria Auxiliadora Ramos Vargas

\begin{abstract}
Resumo
Habitação é um tema vasto que pode ser considerado a partir de perspectivas diversas. Este artigo se propõe a refletir sobre a experiência de grupos afetados por desastres e em processo de vulnerabilização social: a defesa da permanência no seu Lugar de viver e morar se contrapondo à ameaça de desterritorialização vivenciada. Trata-se da experiência de moradia a partir da evidenciação de sentidos que são atribuídos à casa e ao Lugar, apontando para outras dimensões relacionais com o espaço. 0 Lugar revela a adoção de formas de viver, morar e se relacionar com o ambiente nem sempre escolhidas ou revela escolhas que se dão a partir de reduzidas possibilidades, desenhando o desigual acesso a bens e serviços oferecidos pela cidade.
\end{abstract}

Palavras-chave: moradia; vulnerabilização social; desastre; desterritorialização; resistência no lugar.

\begin{abstract}
Housing is a broad theme that may be viewed from different perspectives. This article aims at reflecting on the experience of groups affected by disasters and undergoing social vulnerability processes: they defend the right to remain in their own Place of living in opposition to the experienced threat of deterritorialization. This is about the living experience based on the revelation of meanings that are attributed to the house and to the Place, which point to other dimensions of relations to the space. The Place either reveals the adoption of ways of living and relating to the environment, which, sometimes, have not been chosen, or reveals choices based on reduced possibilities, designing an unequal access to the goods and services offered by the city.
\end{abstract}

Keywords: housing; social vulnerability; disaster; deterritorialization; resistance in the place. 
Quando a seca chega e leva embora as águas do rio Uruguai, as pessoas de Pueblo Federación regressam à sua perdida querência. As águas, ao ir embora, deixam nua uma paisagem de lua; e as pessoas voltam. Elas vivem agora numa aldeia que também se chama Pueblo Federación, como se chamava a sua velha aldeia antes que a represa de Salto Grande a inundasse e a deixasse debaixo das águas. Da velha aldeia já não se vê nem mesmo a cruz no alto da torre da igreja; e a aldeia nova é muito mais cômoda e muito mais linda. Mas eles voltam à velha aldeia que a seca Ihes devolve enquanto dura. Eles voltam e ocupam as casas que foram suas casas e que agora são ruínas de guerra. Ali, onde a avó morreu e onde aconteceram 0 primeiro gol e o primeiro beijo, eles fazem fogo para o chimarrão e para 0 churrasco, enquanto os cães cavam a terra em busca dos ossos que tinham escondido.

Eduardo Galeano (2005)

\section{Desastre, vulnerabilização social, desterritorialização}

Os cenários de desastres socioambientais têm, como uma de suas principais e mais dramáticas expressões, o comprometimento da experiência de moradia e de vinculação com o Lugar $^{1}$ de parcelas sociais significativas, sinalizando para a sua possível associação com processos de vulnerabilização social. ${ }^{2}$ Tal afirmativa revela, já de início, uma adesão à abordagem sociológica acerca dos desastres, sendo essa interpretação apenas uma das que, no debate contemporâneo, integram a disputa pela classificação de tal fenômeno (Bourdieu, 2005). Introdutoriamente, objetiva-se esboçar o conceito de desastres para a Sociologia, o ambiente de disputa por sua classificação e, por fim, sua relação com processos de vulnerabilização e de ruptura de rotinas, práticas e lugares, revelando a realidade de desterritorialização experimentada pelos que são severamente afetados. Tal ensejo quer instigar, sobretudo, a reflexão sobre como tais processos agregam, também, expressões de luta por permanência e defesa do seu território, ainda que sob contestação dos diagnósticos técnicos oficiais.

Reportando-nos às reflexões de Quarantelli (2005) e Valencio (2010), temos que desastres, para a Sociologia, designam acontecimentos trágicos e podem ser descritos como fenômenos adversos que geram processos de ruptura da rotina, de lugares, fazeres e práticas, envolvendo uma configuração espaço-temporal e sócio-histórica para manifestar-se, levando-nos a perguntar "o quê?", "onde?", "quando?" e "com quem?", considerando a adoção dos conceitos de tempo e espaço sociais - em detrimento dos de tempo e espaço geográficos -, assim como observando a relação entre o referido fenômeno e os processos de desenvolvimento.

Apesar da não existência de consenso sobre o conceito, Quarantelli constatará a presença de um paradigma básico implícito na área dos desastres, envolvendo uma série de noções inter-relacionadas, cujo destaque recai 
sobre duas delas, a saber: 1) os desastres são fenômenos inerentemente sociais e 2) a origem dos desastres se encontra na estrutura social ou no sistema social. Para o autor, antes de serem "naturais", os desastres são essencialmente políticos, permitindo a problematização do subdesenvolvimento, da insustentabilidade ambiental e da pobreza como suas principais e mais imediatas causas.

As afirmativas até aqui expostas se revelam como um contraponto à construção hegemonicamente feita sobre esse conceito quando originado de outras clivagens e racionalidades. Porém, as chamadas "ciências da natureza" não respondem à totalidade das formas científicas de argumentação a respeito do fenômeno desastre. Há uma diversidade de agentes que configuram a luta pela sua classificação. Cabe-nos indagar: "quem são e de que lugar esses agentes anunciam suas verdades?". Há também uma diversidade de compromissos de atuação e de fazeres que não se dão da mesma forma. Associada a tais agentes e posicionamentos, está a luta social situada entre dois domínios distintos: do espaço social propriamente dito e da esfera simbólica, no sentido do confronto de discursos e projetos que disputam legitimidade e reconhecimento, em processos intimamente conectados.

Ao admitir e trabalhar sob essa perspectiva, a pesquisa sociológica apresenta mudanças e ampliações importantes, permitindo a constatação de que os desastres se originam da própria natureza dos sistemas sociais, sendo, pois, manifestações ostensivas de latentes vulnerabilidades da sociedade, das deficiências nas estruturas ou em sistemas sociais. Por isso, não devem ser vistos como resultantes de uma forma externa. Deslocam-se o foco das vítimas e as perdas para processos sociais contínuos, pois, não havendo consequências sociais negativas, não há desastre.

Buscamos fazer a associação entre 0 desastre e os processos experimentados por grupos sociais específicos, através das noções de vulnerabilização, como processo, e vulnerabilidade, como relação - conforme contribuição oferecida por Acselrad (2006). Nessa formulação, o foco é retirado do indivíduo e deslocado para a desigual proteção ou para os mecanismos que tornam os sujeitos vulneráveis. Destaca-se o que lhes é devido em termos de proteção social e de direitos, revelando, pois, como tais elementos integram o desastre. ${ }^{3}$

Não só no âmbito de sua definição, mas também das práticas daí decorrentes, explicitam-se conflitos, confrontos, tensões que tendem a impor o discurso oficial do risco sobre territórios específicos e, por consequência, sobre seus agentes, aqueles que neles vivem e moram, determinando sua desterritorialização. Há, tendencialmente, um esforço de desqualificação do território e de seus moradores. Tal prática tende a "coisificá-lo", destituindo-o da diversidade da experiência social que o constitui. 0 "território condenado" resume-se, pois, às suas benfeitorias, edificações e equipamentos de infraestrutura coletiva, passíveis de cálculos de indenização, em grande parte, referenciados em baixos valores, porque se associam à indenização de "áreas pobres" e, até então, desvalorizadas no que se refere às disputas do mercado imobiliário. Pelo lado da significação identitária que os territórios adquirem, tais indenizações, somadas à forma de se traduzir esses Lugares, são incompatíveis com o sentido de pertencimento que enraíza seus moradores a partir de uma trajetória de vida e vinculações. 
Sendo assim, é necessário permitir que os sentidos do Lugar e de pertencimento possam ser também revelados a partir das narrativas dos afetados em desastres, resgatando as estratégias que contribuirão para o esclarecimento de uma das perspectivas que essa disputa assume. Nesse contexto, o Lugar como espaço do pertencimento se apresenta, ora como estratégia, ora como tática resistente à imposição do ordenamento exógeno proposto ao território. Tendo, pois, como eixo central o âmbito socioespacial, a concepção de Lugar pode ser utilizada como relação entre sujeito afetado e o espaço onde vive, como expressão de práticas cotidianas na relação com esse espaço (Certeau, 2009) e da luta pelo direito de acesso à cidade (Lefebvre, 1991). 0 Lugar ganha não só significação, como se revela resultante de uma absoluta determinação, ou seja, da necessidade da adoção de formas de viver, de morar e se de relacionar com o ambiente, nem sempre escolhido, ou de escolhas que se dão a partir de uma gama reduzida de possibilidades. Trata-se de um conjunto de determinações que desenha a desigualdade para além da possibilidade de escolha consciente desses sujeitos.

Assim, é facilitado o entendimento da construção que os agentes fazem do desastre. Então, a categoria Lugar deve ser explorada e perpassada para clarear as vinculações estabelecidas entre agente e território, agentes entre si e entre interpretação do desastre e o sofrimento social por ele aguçado.

Nesse debate, é importante que o Lugar possa ser pensado como forma de enraizamento que precede o "trágico" e o desastre como a ameaça de dissolução desse Lugar e, ainda, a existência de uma luta pela manutenção de seus sentidos, independentemente do grau da destruição física e também simbólica registrado. 0 território periférico deteriorado e impactado pelo desastre não é revisto por aqueles que o têm como referência de moradia e de cotidiano, no sentido de sua desqualificação, o que se confronta com a categoria "área de risco" cunhada para esses mesmos locais pela versão perita.

Em analogia à perspectiva trabalhada por Zhouri e Klemens (2010), ${ }^{4}$ identificamos a existência de estratégias argumentativas de aniquilação do Lugar (predominantemente via discurso oficial) versus a estratégia argumentativa de reafirmação do Lugar (via resistência dos moradores locais). Enquanto os afetados buscam situar o ocorrido dentro de certa generalização dos fatores de ameaça e da afetação - não particularizando o problema no seu espaço e com a expectativa de sua recuperação e permanência nele -, a análise técnica incluirá, no rol de sua cartografização e de diagnósticos, essas novas áreas, até então, "livres" dessa forma específica de controle. ${ }^{5}$

\section{Morar: a perspectiva de reafirmação do Lugar - densidade e ambivalência}

0 contexto dos desastres - nominado comumente "tragédia" na retórica dos afetados -, permite a evidenciação de sentidos que são atribuídos ao Lugar por aqueles que nele vivem, apontando para outras dimensões relacionais com o espaço. Inicialmente, é possível mencionar elementos, quase não explorados na literatura recorrente acerca do tema, constituintes da perspectiva traçada pelos moradores vinculados 
a essas áreas - as denominadas "áreas de risco" -, uma vez que são contrapontos à versão perita para tais territórios: o desvelamento de uma esfera coletiva das representações do território como passível de produção de um Lugar; a revelação de um mundo significativo na rotina da periferia que é também "seguro" e "rico" - dentro da precariedade socioambiental das áreas sujeitas a deslizamentos, enchentes e afins - ou processos de disrupção do cotidiano - aspectos que apontam para a existência de um imaginário social capaz de construir endogenamente sentidos para um Lugar fora do escopo da deterioração.

[...] Eu sinto falta da roça, eu me sinto presa agora [morando em apartamento de aluguel]. Tô num lugar que não tem espaço, meus netos não têm espaço. Eu me sinto muito presa, sempre gostei de ter as minhas coisas, graças a Deus. 0 Senhor me deu! Ganhei muita coisa depois da tragédia. Mas tá faltando sair pra um cantinho que tenha mais espaço que a gente possa se alegrar mais. Eu gosto da roça, dos bichos, de cuidar da terra com foice, facão, tudo na mão. (Entrevistado 13 - Bairro (aleme) ${ }^{6}$

A insistência na permanência ou no retorno ao local de moradia e na reconstrução em territórios tecnicamente condenados aponta para a importância de "um Lugar seu", evidenciando a luta por pertencimento e vinculação, diante da despossessão vivenciada - inclusive a espacial. Estamos tratando de cenas urbanas e rurais que trazem a dimensão tanto da dominação quanto da desigualdade para 0 primeiro plano. Esses locais se configuram em Lugar na medida em que é necessário tornar 0 mundo plausível, vivenciável: uma escolha dentro de uma gama reduzida de possibilidades.
Colabora com essa reflexão a categoria "tática", em Certeau (2009), ou a ação calculada que é determinada pela ausência de um próprio, ou seja, do lugar do poder ou do querer próprios, como supomos se constituir predominantemente o universo dos grupos afetados severamente pelos desastres no caso brasileiro. 0 autor tratará das formas utilizadas pelo "homem ordinário" para escapar à conformação esboçada pela razão técnica que acredita organizar da melhor maneira coisas e pessoas. Esse escape silencioso se traduz na reinvenção do cotidiano graças a táticas de resistências que permitem a reapropriação do espaço e do uso a seu jeito. Certeau afirmará:

Nenhuma delimitação de fora lhe fornece a condição de autonomia. A tática não tem por lugar senão o do outro. E por isso deve jogar com o terreno que lhe é imposto tal como organiza a lei de uma força estranha. Não tem meios para se manter em si mesma, à distância, numa posição recuada, de previsão e de convocação própria: a tática é um movimento "dentro do campo de visão do inimigo" [...] e no espaço por ele controlado. Ela não tem, portanto, a possibilidade de dar a si mesma um projeto global nem de totalizar 0 adversário num espaço distinto, visível e objetivável. Ela opera golpe por golpe, lance por lance. Aproveita as "ocasiões" e delas depende, sem base para estocar benefícios, aumentar a propriedade e prever saídas. 0 que ela ganha não se conserva. Esse não lugar Ihe permite sem dúvida mobilidade, mas numa docilidade aos azares do tempo, para captar no voo as possibilidades oferecidas por um instante. Tem que utilizar, vigilante, as falhas que as conjunturas particulares vão abrindo na vigilância do poder proprietário. Aí vai caçar. Cria ali surpresas. Consegue estar onde ninguém 
espera. É astúcia. Em suma, a tática é a arte do fraco. (Ibid., p. 95)

Há, pois, um conjunto de determinações que desenha a desigualdade para além da possibilidade de escolha consciente desses sujeitos. Retomaremos o recurso sociológico de associação do desastre ao paradigma da vulnerabilidade social. Quando Acselrad (2006) anuncia que a vulnerabilidade é uma relação e não uma "carência", objetiva, acima de tudo, reafirmar que não poderá ser atacada através da oferta compulsória de bens, mas que deverá considerar as relações e os contextos, as diferentes situações e condições que se articulam nos distintos momentos e localizações (p. 5). Decorre daí que o consentimento para com os riscos e danos impostos será tanto maior quanto maior for a destituição (ibid., p. 3). Entram, no âmbito dessa análise, as possibilidades concretas que estão colocadas para certos segmentos populacionais que vivem frequentemente nos limites das condições físicas de reprodução, ou seja, como resultado de uma situação sócio-histórica marcada pela ausência absoluta de opções e de moradia inclusive. Este é um fator que evidentemente impulsiona e cria o pano de fundo da dinâmica de ocupações tidas como "ilegais" e/ou "predatórias" e tão fortemente condenadas pelos discursos técnicos e oficiais, principalmente quando da ocorrência dos desastres. As consequências colocam-se no restrito quadro de oportunidades de localização para os mais pobres, fruto de padrões de produção do ambiente construído e de formas de produção e distribuição desigual da riqueza.

Situando a proteção social no âmbito mais objetivo desse processo, pode-se afirmar que, nele, uns apresentam maior capacidade para se proteger enquanto outros, nem tanto. No primeiro caso, essa proteção é possível pela mobilidade ou pela influência que certos grupos têm no controle do mercado das localizações. No segundo caso, tal proteção se afugenta para aqueles que não a possuem ou que a possuem em baixa ou descendente escala numa dada condição de existência.

Segundo Haesbaert (2004), a natureza dessa mobilidade se faz representar pelas possibilidades relacionais estabelecidas no território. Alguns são protegidos pela experiência da "multiterritorialização"; outros sofrem os limites impostos pela lógica capitalista hegemônica que os atrela ao "território unifuncional". Para o autor,

Desde a origem, o território nasce com uma dupla conotação, material e simbólica, pois etimologicamente aparece tão próximo de terra-territorium quanto de terreo-territor (terror, aterrorizar), ou seja, tem a ver com dominação (jurídico-política) da terra e com a inspiração do terror, do medo - especialmente para aqueles que, com essa dominação, ficam alijados da terra, ou no territorium são impedidos de entrar. Ao mesmo tempo, por extensão, podemos dizer que, para aqueles que têm o privilégio de usufrui-lo, o território inspira a identificação (positiva) e a efetiva "apropriação". Território, assim, em qualquer acepção, tem a ver com poder, mas não apenas ao tradicional "poder político". Ele diz respeito tanto ao poder no sentido mais concreto, de dominação, quanto ao poder no sentido mais simbólico, de apropriação. (p. 1)

Lefebvre (2000) destaca o sentido simbólico das "marcas do vivido" que o território assume e que nos permite falar de apropriação 
em contraposição à dominação: no sentido de apropriação, estariam embutidos o valor de uso e, como tal, a multiplicidade, diversidade e complexidade que o território assume; na segunda, qual seja, na dominação, estaria embutida a sua funcionalidade ou o seu valor de troca. Para Lefebvre, a acumulação capitalista sufoca as possibilidades de "reapropriação" dos espaços que são transformados em mercadoria, impedindo a prevalência da apropriação sobre a dominação. Essas considerações, ainda que preliminares, mostram-se fundamentais no entendimento do que aqui chamamos de Lugar - e dos saberes nessas condições gerados -, no reconhecimento de práticas cotidianas na sua dimensão espacial; tudo isso atrelado à experiência de enfrentamento do desastre que traz em seu bojo a constante ameaça de desterritorialização.

No âmbito dos fatores subjetivos, podemos considerar as diferentes construções socialmente feitas acerca do que é "tolerável" ou "intolerável", do que é "arriscado" ou "seguro", ante condições determinadas de existência. Registra-se certa convivência com eventos pretéritos tidos como ameaçadores que geram sua relativização. As narrativas mostram-se esclarecedoras, evidenciando certa recorrência de fenômenos que marcam a experiência no sentido de sua apreensão e de seu enfrentamento pela necessidade da permanência no Lugar:

[...] a gente pensava que era o rio que estava subindo, que era só água! É onde que, pra baixo, todo mundo morreu, por causa disso. Caso entrasse água, ia acabar com os móveis, mas no outro dia estava tudo bem! Mas aí, não foi só isso. Foi as pedras que veio matando todo mundo! É onde que acabou tudo!! [...] A gente pensava que era enchente, só enchente! (Entrevistado 28 - Campo Grande)

[...] meu pai sempre fala com a gente: "choveu, de vez em quando, dá uma olhada no rio, apesar dele tá longe", porque isso aqui é um valão, é morro de um lado e de outro e aqui é uma descida, e aqui é um bairro que tem muita água. Se você andar por essas trilhas, eu te levo em lugares que tem muita água, tem cachoeira. Então, quer dizer, eu não sei na cabeça dos outros, mas meu pai sempre foi uma pessoa assim, apesar que a gente sempre morou perto de rio, ele sempre falou: "se ver que a chuva não tá normal, sempre dar uma olhadinha, sempre ter uma atenção!" (Entrevistado 21- Bairro Campo Grande)

Conviver com tais fatores de ameaça faria parte daquilo que Vargas (2006) menciona como sendo lidar apenas com mais um elemento componente do cenário de privações e demandas que está no plano mais imediato - ameaças, pois, que se tornariam contornáveis e passíveis de convivência. Então, não se trata da negação desses fatores, como se pode num primeiro momento inferir, mas de sua secundarização. ${ }^{7}$ A leitura dos "sinais da natureza" e a apreensão de elementos que caracterizam a paisagem, sua constituição biofísica, na tentativa de seu "controle", mostram-se como um misto entre convivência e observação do Lugar e noções apreendidas, ainda que, parcialmente, do próprio discurso perito (geológico, meteorológico, originadas da geotécnica, entre outros). Nas narrativas seguintes, moradores e um técnico interpretam os territórios e suas características geológicas revelando uma convergência para a leitura produzida pela geologia: 
Teresópolis é um lugar que está sobre a pedra. É uma cidade alta. Essas pedras já estão aqui há milhões de anos [...] durante esse tempo foram sendo depositadas sobre essa laje de pedra materiais... essa área todinha tem pedra embaixo. Mas você vê vegetação em cima da pedra, vê que tá na terra acumulada sobre a pedra ao longo dos anos. É pedra com camada de terra e vegetação. Se chove muito, ela vai lavar isso. Olha aquela montanha: pedra pura! Essa outra aqui do lado, também... Essa base nossa aqui é de pedra e é continuação daquela montanha, etc. 0 que está aqui foi depósito feito ao longo dos anos: depósito de poeira que veio ao longo dos anos, a gente não sabe quantos e que se acumulou. (Entrevistado 6 - Bairro Caleme)

[...] e as pessoas se perguntam: "de onde veio tanta pedra?" Foi por isso que até se fez pesquisas com os geólogos e tudo, pra mostrar qual era o tipo de relevo mesmo de Teresópolis. E aí, se descobriu que Teresópolis é uma grande pedra. Debaixo de toda a cidade você tem uma camada de terra relativamente pequena. Aí, os engenheiros, arquitetos é que devem explicar. Parece que realmente não é nada muito profundo e você tem muita pedra indo diretamente a essa camada, então, qualquer chuva, qualquer coisa maior faz com que aquela terra que é muito pequena, desça e apareçam as pedras. (Entrevistado 16 - Secretaria de Desenvolvimento Social/PMT)

Os elementos mencionados até aqui compõem a noção de Lugar pelos agentes, e a retórica perita/técnica envolverá, direta ou indiretamente, tais construções. Qual seja, tratamos de perspectivas que, num dado momento das narrativas, fazem certo movimento de convergência para o conteúdo das referências técnicas, ainda que isso não seja claro para os agentes e que essa forma específica de entendimento não use dos jargões da ciência, necessariamente. Haveria, pois, uma apropriação do ambiente influenciada pelas estratégias discursivas oficiais, fortemente divulgadas, principalmente por ocasião da deflagração do desastre. A força que a gestão e a tecnociência (Valencio, 2012) ganham contribui para a projeção de ideias, noções, ferramentas específicas que impregnam o imaginário social e interferem na forma de os agentes mais diretamente afetados pelo processo o traduzirem, ainda que sua ótica e experiências não sejam consideradas diante das decisões que afetam o seu cotidiano e o da comunidade à qual pertencem.

Mas olha, a pesquisa tá tão evoluída. Um exemplo: a sombra da minha mão é o Caleme e aqui tem uma nuvem. Eles sabem qual é o tamanho e a grossura dessa nuvem. Sabem a distância entre a nuvem e o chão se é de $12 \mathrm{~km}, 15 \mathrm{~km}$. Eles sabem onde ela tá estacionada e ela estava da Várzea [bairro central] pra cá... Sabe por que eles sabem? Nós estamos aqui conversando. Eu te garanto que eles nos lugares de pesquisa mais evoluídos sabem que eu tô sentado aqui e ele está em pé. Eles dizem até o que você está comendo. É satélite! Então, o cara não sabe que vai chover? Diz pra ele, quantos minutos o satélite leva pra dar uma volta na terra? Se você reparar no jornal quando eles mostram aquela foto de satélite, ele dá a cada 11 minutos uma volta na terra, ele anda na mesma velocidade de uma espaçonave quando está em órbita e leva 11 minutos pra dar a volta ao redor da terra. Já pensou? Em cada 11 minuto você está aqui de novo. Então, a cada 11 minutos o cara tem a previsão daquela área onde passou. Ele passa investigando a área 
todinha, então, como a altura dele é muita, ele vê onde tá acontecendo. (Entrevistado 6 - Bairro Caleme)

Nessa reflexão, as narrativas contam aos poucos a história de vinculação com o Lugar, de apropriação do território que está diretamente associada aos processos de desenvolvimento e ao ordenamento territorial mais geral. Os dois territórios urbanos envolvidos na pesquisa Caleme e Campo Grande - situam-se em finais de vales que foram ocupados há aproximadamente 50, 60 anos e forma adensados nos últimos 30 anos, conforme relato de seus moradores mais antigos. Originada de um integrante da gestão municipal, a narrativa seguinte facilita o entendimento acerca das características que marcam 0 adensamento que a cidade como um todo viveu nas últimas décadas:

Eu vim do Rio de Janeiro por conta de violência! Tudo bem que 20 anos atrás nem era esse tanto de violência que é hoje, mas a gente já veio com essa visão de sair do Rio por conta da violência. E hoje em dia é muito maior a proximidade de Teresópolis com Rio de Janeiro. A gente leva uma hora e meia, duas horas de ônibus: é o tempo que você leva da Barra da Tijuca até o centro da cidade morando dentro do Rio. Então, você tem uma qualidade de vida melhor em Teresópolis por causa do clima, um ambiente mais seguro para os filhos adolescentes, ainda se pode andar de noite na rua. Você não tem arma na cabeça quando para no trânsito, não tem caixa eletrônico explodindo, enfim, você tem uma certa segurança aqui ainda. Existem aqui os traficantes, enfim, mas é em menor escala e, aí, você faz com que Teresópolis lote de gente. Qual é o grande problema de Teresópolis? As pessoas procuram os centros urbanos que é onde tá centralizada ali toda parte de comércio, banco, as unidades, órgãos públicos.Teresópolis tem uma área rural muito boa, muito grande, até eu tinha uma grande vontade de morar pra Vargem Grande. Depois do negócio que aconteceu em janeiro, eu mudei de ideia, mas você não tem essa área rural muito habitada. Tem uns condomínios maiores de uns 5 anos pra cá. Você tem uma leva de condomínios de classe média, classe alta pra esses locais. Se você andar aqui, você vai ver bastante de Albuquerque pra lá em direção a Friburgo bastante condomínio de casas grandes, você vê que já é gente que tá morando mesmo, nem usa só pra veraneio, não! Gente que mora e desce pro Rio, vem pro centro e tal! Mas assim, é isso! Eu acho que Teresópolis tem uma população pobre muito grande por conta: primeiro pela topografia da cidade, não tem jeito, você vai morar naquilo mesmo e até gente aqui que mora na Várzea que é a parte baixa do centro da cidade, que é o reto, você vê que não é tão reto assim. Aqui, por exemplo, na nossa Secretaria tem uns morrinhos aqui do lado e nós estamos, teoricamente, na parte baixa, né? Há pouco tempo, por conta da tragédia, eu até fui em algumas reuniões do Ministério Público e tal, e ela tava mostrando uns mapas, mostrando como que é o terreno de Teresópolis: a camada de terra que tem aqui é muito pequena em profundidade. Em Teresópolis, como é região serrana, parece que é a característica dos três municípios: Teresópolis, Petrópolis e Friburgo. (Entrevistado 16 - Secretaria de Desenvolvimento Social/PMT)

No entanto, quando nos atentamos às narrativas dos moradores, encontramos certa disposição em interpretar "seus Lugares" não a partir da ênfase em possíveis carências ou irregularidades existentes - ainda que possam ser objetivadas e componham seu quadro de 
vulnerabilização -, mas sim das vinculações materiais e também de natureza simbólica já criadas. Ao contarem as histórias de ocupação/formação dos seus bairros, realçam, antes de tudo, a perspectiva relacional, cotidiana, as conquistas (pessoais e coletivas) e mesmo o sentido de "oportunidade" (Vargas, 2006) que tal inserção simbolizou na sua trajetória de vida - e que se mantém na luta travada pela permanência no Lugar.

Tem de 32 a 33 anos que eu moro aqui. Quando eu vim pra cá não tinha muitas casas, a rua não era calçada, não tinha ônibus até aqui. Eu só saio daqui direto pro lugar pra onde nós vamos todo mundo [...]. Foi meu pai que me deu essa terra aqui. Ele morreu aqui e minha mãe também, aqui é de família, entendeu? E tenho meus amigos, a molecada toda gosta de mim. É só você perguntar: "onde mora o velho" que todo mundo me conhece. Aqui eu crio minhas galinhas e outros bichos e tenho meus pés de fruta. (Entrevistado 2 - Bairro Caleme)

0 bairro cresceu tem uma faixa de uns 50 anos, né? Tô aqui há uns 50 e poucos anos [...]. Quando eu vim pra cá pro Caleme eles estavam ainda querendo construir a barragem. Então, que cresceu mesmo esse bairro aqui tem uns 30 anos que começou a evoluir. Aqui era quase só parente antes. Depois começou a evoluir, o tio dela arrumou um carrinho, o primo lá embaixo comprou um carrinho. Já tinha um carrinho pra sair aí pra fora, viajar. Eu acho que cresceu devido ao fato do lugar ser muito tranquilo. Muita gente veio, começaram a vender os terrenos. Esse terreno aqui, a gente não tinha escritura de nada. Alguém aí tem um papel e diz que tem escritura do terreno, mas não tem nada! Era de uma Cia que tinha aqui em Teresópolis. Depois, a casa da Cia pegou fogo e os documentos sumiram tudo. Então, ficou esse lugar aqui assim. 0 pessoal começou a tomar conta do pedaço. Meu sogro mesmo, pegou daquela ponte que tem abaixo da padaria até lá em cima. Isso aqui era dele, ninguém mexia. Cada um pegava um pedaço, cercava e dizia: "é meu!" E foram fazendo casa e começaram a vender. Meu sogro mesmo vendeu isso tudo aqui, ali pra baixo. Trocava por qualquer coisa. Trocou por material que nem tinha valor nenhum. (Entrevistado 17 - Bairro Caleme)

Moro aqui há 44 anos. Vim do Rio pra cá com 1 ano de idade. Aqui, eu já morei no haras que tem perto do campo, lá em cima. Daí, me casei e fui morar lá embaixo em Santa Rita e depois vim pra cá [Fazenda Alpina]. Nessa casa tem 4 anos que eu vivo. Aqui a gente fala Fazenda Alpina. Santa Rita fica mais pra baixo, lá embaixo. Mas Fazenda Alpina faz parte de Santa Rita. Antigamente, chamavam "Engano", depois Fazenda Alpina. Aí fala: Fazenda Alpina/Santa Rita. (Entrevistado 31 - Bairro Santa Rita)

Evidencia-se, nesse conjunto, o movimento de crescente ocupação física com ênfase na constituição da moradia e dos serviços que são destacados como os mais essenciais no cotidiano dos moradores: o transporte, a educação, o pequeno comércio, os mesmos mencionados como as principais carências para os que permaneceram nos locais impactados, gerando, entre outros, um sentido de "vazio" e de "solidão" enquanto simbologia de rompimento também dos fluxos do Lugar, qual seja, de mobilidade, liberdade de ir e vir, possibilidade de manutenção de hábitos cotidianos, como comprar o pão no comércio mais próximo, e do lazer e diversão (futebol, sinuca), assim como da manutenção da dinâmica alegre da reunião 
de crianças e de adolescentes nas manhãs e tardes de entrada e saída da escola local.

[...] Eu tive que passar setenta dias fora, depois eu voltei pra cá, mas estou sentindo falta do movimento, daquela bagunça, daquela gente que descia pra jogar futebol, porque tinha um campo que a gente, às vezes, vinha bater uma bola. Olha, muita gente diz que Campo Grande tinha três mil pessoas, mas eu calculo que devia ser duas mil pessoas. Quando veio o dia da tragédia, eles não foram embora de noite, porque não tinha como eles ir, tava chovendo, aí a chuva acabou já tava quase amanhecendo, aí eles não iam descer sem caminho, no escuro. Eu cheguei ali e vi pouca gente, morreu muita gente, eu calculo umas mil pessoas, ou umas mil e duzentas pessoas. Mas a água aqui passou por cima de casa de dois andares. Inclusive tinha um casal que tava na praia, eles vieram pra cá naquela noite, e viram eles em cima da casa. Então, o pessoal pensava que eles não estavam em casa, viram eles em cima da casa, o casal com duas crianças, e quando dava um relâmpago eles gritavam pedindo socorro, e ouviu uma vez. Mas quando deu o relâmpago de novo, eles não tava mais, a água passou por cima da casa, eles chegaram em casa de noite e não amanheceram em casa. É triste, não é? Eu acho que aquele povo, muita gente não vai ter nunca mais, eu acho que esse ônibus nunca mais vai até lá em cima [antigo ponto final]. Eles tão indo lá pra cima pra derrubar as casas, eles não fazem nada pra ajudar a consertar a rua. Bom, eu gosto daqui, a água aqui é muito boa porque é de uma nascente ali em cima. Aqui é um lugar muito sossegado, aqui a gente pode dormir com o portão aberto entendeu? Não tem perigo nenhum, aí quando o meu filho sai e deixa a porta aberta, a pessoa pode chegar e entrar. Eu fiquei muito tempo sem sair de casa, pra ir ao médico o meu filho arrumava um carro. Aí o ônibus tá vindo até aqui em cima agora, agora ficou bom de novo. Mas agora a gente tá esperando que eles asfaltem a rua aqui e que afundem o rio porque quando enche o rio, desce pela rua e estraga a rua tudo de novo. Olha, eu tô achando que é muito ruim pra gente sair de noite, fazer compra: se voltasse aquele mercadinho aqui embaixo seria bom, melhorar a rua, aí eu preferia ficar aqui. Tava muito bom! Aqui tinha uma padaria que vendia todo tipo de fruta, uma birosca lá em cima e lá tinha uma mesa de sinuca. E o pessoal se divertia muito. Aqui tinha até o grupo das mulheres que a gente jogava bola no sábado. (Entrevistado 26 - Bairro Campo Grande)

As considerações compreendem a perda de fixos e fluxos, assim como a perda "dos outros". Então, o desastre é "a falta de todo mundo", a dificuldade de manutenção da vinculação com o Lugar e com as pessoas que o integram, porque morreram ou porque, aos que permaneceram vivos, não foi permitido o retorno.

Na conformação do Lugar que se faz identitário, é interessante observar certa convergência entre as três localidades pesquisadas esboçadas nas narrativas - Bairros Caleme e Campo Grande e Distrito de Santa Rita -, principalmente considerando a mobilidade já experimentada por alguns entrevistados entre as três áreas, assim como por vínculos de parentesco existentes nas outras localidades ou mesmo apenas pelo conhecimento que se tem das histórias locais, com as quais é possível verificar forte identificação. Na verdade, são territórios que apresentam características semelhantes no que se refere a histórico e tempo de ocupação, padrões construtivos, 
infraestrutura e formas de vida, de maneira geral, facilitando certa aproximação identitária com seu próprio Lugar.

Quando dos relatos acerca do ocorrido em 12 de janeiro de 2011, foi comum o deslocamento de suas interpretações para o outro território, no sentido do reconhecimento de um também sofrimento experimentado por "semelhantes".

Lá no Campo Grande acabou. Eu não tive coragem de ir lá. Muita, muita gente conhecida da gente! Uma família toda conhecida da gente! Foram membros da Igreja junto com a gente. Filho, neto da irmã da Igreja. Lá foi muita gente conhecida, não tenho vontade de ir lá. Tem um mês, encontraram o corpo de uma senhora lá, perfeitinho. (Entrevistado 17 - Bairro Caleme).

O meu filho trabalha lá pro lado de Fazenda Alpina/Santa Rita. Ele disse que lá choveu mais do que aqui. Lá, no Caleme, os primeiros moradores de lá do Caleme foi meu avô, o José Francisco de Melo. Papai foi criado lá. Todos lá, a maior parte é meus primos que eu nem conheço. Lá foi aumentando e tá quase uma cidade, né? (Entrevistado 26 - Bairro Campo Grande)

Lá em Campo Grande era meu mesmo, foi a primeira casa que eu comprei [...]. Nossa, lá eu conhecia as casas a dedo! Eu conhecia tudo. Depois lá foi crescendo. Agora, nessa época, fiquei um bom tempo fora e ali já tinha bastante gente que eu não conhecia. Não consegui voltar lá depois do que aconteceu. Eu tenho uma conhecida lá que tá sumida. Eu fui até o ponto final [do ônibus] mas não consegui: só em ver a primeira casa ali do ponto da igrejinha... (Entrevistado 13 Bairro Caleme)
Pensar essas localidades nos permite avançar em traços particulares de sua constituição. Elemento fundamental na caracterização dos vínculos formados diz respeito à conservação de fortes traços suburbanos e relações sociais ainda bastante tradicionais e familísticas, nos termos de Martins (2010).

Aqui a gente conhecia os mais velhos, os mais novos, quem casava, quem tava namorando, quem tava esperando neném [...]. Aqui, quando uma fazia uma arte, todo mundo ficava sabendo: "ih, tá namorando escondido". Era assim. (Entrevistado 27 - Bairro Campo Grande). ${ }^{8}$

Nesse conjunto de importâncias e reflexões, destacamos o papel da casa como "espaço vital" e a forma própria como é feita e habitada, contribuindo para o entendimento do enraizamento dos sujeitos, tanto nesse espaço mais restrito, como na sua extensão mais coletiva ou na experiência comunitária, reproduzindo-se de acordo com todas as dialéticas da vida, segundo Bachelard (1998). Talvez não haja, no âmbito dos fixos presentes na análise dos desastres, componente mais enfatizado do que a casa. Na perspectiva do autor, a moradia está relacionada à proteção e é concebida simbolicamente como "concha", ou seja, o "primeiro universo", um "cosmos", nosso "canto no mundo". Considerada para além de ser um objeto, expande-se de sua positividade para o mundo dos sonhos, no qual "as diversas moradas de nossa vida se interpenetram e guardam tesouros dos dias mais antigos" (p. 25). Bachelard quer mostrar que 
[...] a casa é uma das maiores (forças) de integração para os pensamentos, as lembranças e os sonhos do homem. Nessa integração, o princípio de ligação é o devaneio. 0 passado, o presente e o futuro dão à casa dinamismos diferentes que não raro interferem, às vezes se opondo, às vezes excitando-se mutuamente. $\mathrm{Na}$ vida do homem, a casa afasta contingências, multiplica seus conselhos de continuidade. Sem ela, o homem seria um ser disperso. Ela mantém o homem através das tempestades do céu e das tempestades da vida. É corpo e é alma. É o primeiro mundo do ser humano [...]. A vida começa bem, começa fechada, protegida, agasaIhada no regaço da casa. (Ibid., p. 26)

Apropriando-se do autor, (2012) ilumina essa reflexão considerando que:

[...] a construção inicial de identidade e as relações fundamentais com o outro, em termos de cuidados mútuos, solidariedade e afetividade, são protegidas pela moradia [...], concebida como um locus onde a intimidade é resguardada para o repouso, o devaneio, a satisfação das necessidades básicas, dentre outros. Trata-se de uma referência espacial essencial dos residentes para dar materialidade aos seus valores, desejos, aspirações, fantasias, sentimentos, assim como para exercitar as tensões e conflitos que, porta afora, estarão igualmente presentes na esfera pública. É, ainda, a referência espacial relevante na sociabilidade praticada com os demais membros de sua rede primária, desde os oriundos da família nuclear como da extensa, como os amigos e vizinhos. A referência alargada da moradia, que faz a ponte entre a esfera privada e a pública, as práticas pessoalizadas e as impessoais, é a comunidade, cujo sistema de objetos com significados compartilhados viabiliza a coesão e rotinas de convivência entre conhecidos e desconhecidos. (p. 68)
Campo Grande foi um bairro que revelou a característica da sociabilidade levantada pela autora, apontando para conjuntos de moradias que agregavam toda a família:

E lá era assim: tudo perto, em família. Era um terreno que tinha cinco casas: a minha sogra, a minha cunhada, minha outra cunhada, eu e meu marido e tinha um sobrinho dele que tinha uma casinha lá também [...]. (Entrevistado 4 - Bairro Campo Grande)

Eram 4 casas: da minha cunhada e meu cunhado... eram, na realidade, 5 casas porque o outro cunhado solteiro ele tava construindo por cima da casa do irmão dele, já tava com meia parede de tijolo levantada; como a casa do irmão dele foi levada por inteiro, a dele foi junto. Só a que ficou inteira e não caiu nada foi a minha casa e a do meu sogro. Já a da minha cunhada que era no segundo andar, a sala foi destruída e a garagem, a cozinha, banheiro e quarto. A varanda da cozinha, onde ela até tinha uma lojinha de doce ficou intacta, só atingiu mesmo a sala e a garagem. (Entrevistado 20 - Bairro Campo Grande)

O terreno era assim: a gente fala que é meu, mas como dizem, a gente não tem nada, aqui é de Jesus. Jesus emprestou pra gente viver até agora, né! Então, tinha a casa dele, que é da minha filha, e tinha a casa do outro filho que eu deixei ele fazer em cima da minha, e eu morava na de baixo. E foi tudo embora numa pedrada só! Tinha outra mais pra baixo que meu genro tinha acabado de construir. Já tinha gastado um dinheirão, estava quase pronta, só faltava botar porta e a cerâmica. Aí levou tudo! Já tinha gastado 15.000,00. (Entrevistado 27 - Bairro Campo Grande) 
A perda da moradia, ou do sentido de proteção da "concha", torna-se, pois, um forte componente do sofrimento experimentado no contexto de desastres, passando a representar a maior expressão da luta dos grupos sociais afetados na reconstituição das referências perdidas.

A perda da casa - por danificação, destruição ou interdição desse espaço pelas autoridades públicas - é a perda de uma possibilidade de recolhimento do eu no espaço de sua intimidade, isto é, naquele que lhe permite o repouso, o devaneio, 0 ato amoroso, o exercício experimental dos papéis na vida pública - enfim, o que Levinas denomina como a interioridade do ser; e o que Bachelard já havia refletido ao destacar que a casa e o corpo se confundem e qualquer desventura que abale os alicerces da casa abala o sujeito que nela vive, ali delineia sua identidade e em cujos porões são guardados os seus medos indizíveis. [...] tirar a casa de alguém é uma expressão de poder, para lembrar que quem dali é expulso não tem mais raiz e está solapado no direito de reivindicar refúgio e proteção. A perda da casa por um ato de força [...] significa também atacar o mundo interno do morador, colocá-lo a nu e lançá-lo ao exílio, impedi-lo de defender-se do ataque das tempestades da natureza e das tempestades da vida. (Valencio, 2014, p. 304)

Três grandes enfrentamentos parecem nascer daí: a passagem pelos abrigos públicos temporários (na condição denominada "desabrigados") ou o alojamento na residência de conhecidos ou familiares (na condição de "desalojados"); a inserção nos programas de aluguel social, estes geradores de profundas inseguranças e desconfianças na relação com o Estado (agravado, naquele município, pela falta de oferta de imóveis para aluguel, pela alta dos preços dos existentes ou, ainda, pela resistência do município em firmar esse contrato com parcelas dos grupos afetados, conforme denunciado pela Associação das Vítimas das Chuvas do Dia 12 de Janeiro de 2011 em Teresópolis - Avit); e, ainda, o total descompasso entre as expectativas dos afetados e as propostas de reassentamento via programas de moradia planejados unilateralmente pelo Estado.

A defesa do Lugar passará pela luta na busca pelo seu refazimento: este é fato recorrente nesses cenários e se torna o mote dos movimentos desencadeados a partir dos desastres, de maneira geral. Os moradores contestam as experiências de demolição das edificações atingidas no desastre e/ou daquelas condenadas pela avaliação técnica de risco por diferentes razões, principalmente: por não verem, em grande parte dos casos, a necessidade, em se tratando daquelas edificações que permaneceram intactas e que têm "indicação preventiva de demolição" - e, daí, é revisto todo o sacrifício que a conquista da moradia representa historicamente para esse segmento social; e porque as demolições agregam mais componentes ao aspecto de destruição e desertificação do Lugar, tudo isso se somando à ausência de ações de recomposição local por parte do Estado, traço marcante do caso da Região Serrana do Rio de Janeiro - o que só reforça o aspecto de disruptura social característico dos desastres - num plano mais imediato, materializado pelo meio físico. 0 Lugar é tratado como impossibilidade.

No referido contexto, a expressão "lá fora" foi sempre utilizada nas narrativas para o tratamento de qualquer outro ponto da cidade que não fosse o seu próprio Lugar, criando certa 
distinção acerca do espaço "conquistado" e "seguro", no sentido de lhe ser pertencente, acima de tudo, pela identidade e pela proximidade com seus hábitos, relações, afinidades e, mesmo, com as táticas que envolvem sua sobrevivência. 0 aspecto outsider ${ }^{9}$ presente na perspectiva tanto da "área carente" como da "área de risco" - agregado a tais territórios a partir da retórica oficial - é ressignificado quando a vida e o cotidiano se revelam atrelados a aspectos que lhes asseguram o sentido de pertencimento. Não se quer aqui afirmar o sentido de Lugar isento de restrições, uma vez que não é traduzido nas narrativas como "idealização romantizada" e inclui o reconhecimento das limitações que lhe são impostas (e os próprios aspectos classistas inerentes a essa condição). Contudo, cabe enfatizar: os sentimentos de pertencimento e segurança permanecem diretamente associados a esse "Lugar identitário", ainda que, em muitos aspectos, explicitamente restrito e segregado.

É um bairro de pessoas pobres, muitos aqui não estudou. Então, eram pessoas que realmente viviam aqui dentro do bairro: a gente tinha um mercado; bem ou mal, vinha um pediatra, vinha um ônibus de dentista, então, assim, muita coisa a gente tinha aqui dentro do bairro. 0 que você realmente tinha que fazer lá fora, você ia fazer. Só porque aconteceu aqui [o desastre], não quer dizer que seja só aqui. Isso acontece em vários lugares. Então, um dos objetivos de voltar pra Campo Grande, além de amar realmente muito esse bairro, não só eu, mas os meus filhos também, o meu maior princípio, eu conversei muito com Deus e falei: "Deus, se for da Tua vontade que a minha casa seja liberada, se for da Tua vontade que eu venha pra ajudar o povo, porque eu não perdi nada, mas eu quero ajudar quem perdeu. As únicas coisas que eu perdi foram os meus vizinhos, os meus amigos, isso sim, porque se eles tivessem aí, já tava bom. 0 pobre já tá acostumado a sofrer, a lutar, isso a gente reconstrói com o passar do tempo. A gente sente a falta de todo mundo. Porque sexta, sábado e domingo as crianças tavam na pracinha brincando, soltando pipa, né? Todo mundo era conhecido. Aqui é tranquilo. As pessoas lutam, mas, se o Governo não ajudar a gente, o que é que adianta? Se tirar daqui vai colocar onde? Vai enfiar onde? As pessoas que receberam dinheiro aqui não tão conseguindo nem comprar uma casa. Você vai comprar num bairro que não é como aqui, que tem tiroteio direto, tem drogas. Aqui era um bairro mais família, mais roça, mais tranquilo. Mesmo antes da tragédia, o silêncio que você tá vendo aqui, era assim. 0 agitamento maior era depois das cinco porque as crianças começavam a sair do colégio e nos finais de semana, porque aí as crianças saíam correndo. Aqui sempre tem a época de pipa, de pião, de gude, então, as crianças corriam pra lá e pra cá. [...]. É um bairro que tem reconstrução, se não dá onde tinha as casas, tem outros lugares que dá pra fazer. Qual é a do Governo? Não tá se importando de te tirar daqui, se você vai ter casa pra morar, onde você vai enfiar seus filhos. Tem gente aqui que tá sem o aluguel social, e tá lá fora pagando do bolso, passando uma dificuldade danada, né? Então, fica complicado. (Entrevistado 21 - Bairro Campo Grande)

"Lá fora" compõe, então, o discurso de reafirmação do Lugar em contraponto a outras e diferentes ameaças: ao que está distante e desassociado e, até mesmo, ao estranhamento que as tramas da cidade podem gerar às suas práticas sociais específicas. A precariedade 
objetivada é amenizada pelo sentimento de pertença e o contrário também se revela: a precariedade ganha, de fato, maior relevância quando se pensa a experiência "fora do seu Lugar identitário". ${ }^{10}$

Quando a gente morou "lá fora", eu não me adaptei de jeito nenhum! Tem gente que não quer voltar [para o bairro de origem], mas eu, depois que voltei, eu durmo melhor. A gente vive mais tranquilo. Aqui tem muitas pessoas conhecidas [...], eu me sinto bem, em paz, tranquila. Fora daqui é difícil! (Entrevistado 20 - Bairro Campo Grande)

0 sentido de Lugar se traduz, pois, de diferentes formas. Como tais territórios possuem fortes características interioranas e suburbanas, é registrada a ênfase na tranquilidade que o cotidiano permite (silêncio, liberdade, simplicidade, informalidade no trato) e na pessoalidade das relações. Isso se opõe às características tidas como próprias do ambiente urbano, ou seja, o "tumulto da cidade", os desafios colocados por uma dinâmica não absorvida, a invisibilidade das pessoas. "Aqui é bom, é tranquilo, sossegado. Não tem violência e a gente se sente à vontade." (Entrevistado 5 - Bairro (aleme). 0 "interior" - outra expressão localmente usada para se referir à zona rural, mas que também converge claramente para os fragmentos territoriais urbanos que não estão na área central do município - é traduzido pelo que proporciona em termos das redes de sociabilidade que facilitam a sobrevivência e suprem, até certo ponto, a ausência ou precariedade do trabalho/renda e das políticas voltadas à reprodução social, de maneira geral.
Eu te digo na honestidade, eu quase não saio do bairro. Às vezes eu chego lá na cidade e penso: "fizeram essa obra, e fizeram isso aqui" e as pessoas falam " $R$., mas tu mora em Teresópolis". Aí eu: "é, eu moro lá em Teresópolis, mas eu adoro ficar lá no meu bairro, e minha vida é lá, eu gosto de estar com os amigos, gosto da tranquilidade, eu não me vejo no meio de muita agitação, eu gosto da paz de saber que eu vou sentar num lugar pra conversar, vou rir, não tenho que me preocupar com nada, porque infelizmente, 0 mundo de hoje te obriga a trabalhar. Te obriga a viver aquela vida estressante $e$, de repente, você sabe que você tem o seu bairro e é tranquilo e calmo, tu sabe que você vai ficar ali na tranquilidade. Eu pelo menos gosto. Nada muito cheio, muito movimentado. (Entrevistado 21 - Bairro Campo Grande)

Eu gosto muito dali [local onde morava]. Meu caso é ficar ali. Se caso não tiver outra solução, tenho que aceitar para onde me mandarem ir. Mas o meu marido não, ele chega a passar mal quando fala que ele tem que sair dali. Passa mal mesmo, ele desce fica lá pensativo no que fazer. Nos primeiros dias depois da tragédia eu fiquei no hospital com o menino dois dias [...]. Quando eu vim os vizinhos me contou que ele ficava sentado chorando. Já tem 33 anos que ele mora aqui. Construímos do começo até o fim. (Entrevistado 3 - Bairro Caleme)

Movimento, muito bom! Aqui tinha movimento, festa... Esse meu cunhado que morreu, ele tinha uma birosquinha. Ele fazia forró, festa junina. Era normal. Vinham uns caras de fora cantar! Agora... Quem tem televisão fica dentro de casa vendo TV, quem não tem, vai dormir. De 
vez em quando ainda tem uma festinha na casa de amigo, um churrasquinho... Mas mudou muito, muito, muito! Encontrei esses dias uma amiga minha. Quando ela me viu, ela me deu aquele abração: "pensei que você tivesse morrido!". Porque falaram que Santa Rita acabou, que todo mundo morreu. Morreu muita gente, mas não foi todo mundo. É difícil! Porque é interior, a gente é unida, se gosta, todo mundo se comunica um com o outro. Todo mundo se dá, graças a Deus! Às vezes tem até uma maldade, mas é gente de fora quando vem. Pessoal daqui, que foi criado aqui, todo mundo se dá bem. Vamos supor: se alguém tá com um carro, uma moto quebrada no caminho, para pra ajudar. Se alguém passa mal e não tiver carro, pode ir no vizinho que ele leva, entendeu? (Entrevistado 31 - Bairro Santa Rita)

É possível reconhecer nessa interpretação, ou na crítica dos afetados, um descolamento entre a ideia técnica de risco fortemente propagada e a defesa de reconstituição do Lugar. Toda a discussão acerca da moradia é perpassada pela constatação da existência daquilo que consideram equívocos ou morosidade/ineficiência na atuação do Estado, levando a manifestações de total desconfiança com relação à efetividade das ações prometidas. Subitamente, passam a interagir com frações desse Estado que, até então, não integravam suas experiências no Lugar, revelando inclusive a dificuldade de assimilar suas identidades e papéis.

[...] Agora é a tal do Inea. Agora é esses, só que esses demoliram a casa aqui de baixo e eles limparam. Eles falou que o negócio deles é demolir limpo; os primeiros, não: você pode ver aqui em cima que as casas que eles demoliram e só juntaram o lixo mais ou menos e tá assim horrível. Porque, às vezes, as pessoas chegam e não sabe se foi pela chuva, porque muitos que vêm aí perguntam se foi a chuva. Aí, eu falo: não, foram as máquinas! (Entrevistado 20 - Bairro Campo Grande)

A Defesa Civil interditou algumas casas. Depois, voltou ao local e liberou a casa. 0 dono da casa não quer mais a casa, pediu pra marcar e destruir. E por que não distribuir essas casas pra quem perdeu as suas? Derrubaram casas boas, que estavam liberadas e têm pessoas esperando casas pra morar. Eu moro no Loteamento do Feu, minha casa não aconteceu nada e tá lá marcada pra derrubar. Já estiveram lá, já mediram, tô esperando me chamar. Se me der um dinheirinho de acordo, eu vendo a casa, se não der, não tem condições. Lá perto de casa têm casas que foram liberadas, o dono não quer mais, falou com a Defesa Civil pra marcar e derrubar. Ele tá recebendo aluguel e certamente vai receber um apartamento desses que tão prometendo aí, que é difícil. Poderiam aproveitar essa casa, inclusive eu tenho vizinhos lá que aceitam a casa. Se vai derrubar a casa, que não derrube, mas dê pra outros. (Participante da Audiência Pública 2)

Quero fazer uma pergunta para as autoridades competentes: "quando vai acabar de ser feita a infraestrutura dos bairros, do Poço dos Peixes onde a obra começou e parou, a limpeza de rio, barranco?". E quero repetir a pergunta que já foi feita sobre as casas que pediram pra serem marcadas: se tem como fazer uma reavaliação e dar as casas pra quem tá precisando. (Participante da Audiência Pública 2) 
São interpretações que se opõem à forma utilitária como o Lugar é tratado pelas instituições do Estado na sua lógica de "refazimento do cenário destruído pelo desastre". A significação que a conquista da moradia tem e a necessidade de garanti-la se mostra contundente nas estratégias discursivas utilizadas pelos agentes desse Lugar. 0 tratamento dado, pois, pelas instituições do Estado é contestado, uma vez que sua ação se rebate no cotidiano de diferentes formas: através do seu esvaziamento, na ainda maior redução da mobilidade e no isolamento, sentimento de solidão e abandono para os que ficam e de desvinculação para os que são obrigados a sair definitivamente através das remoções compulsórias. São serviços públicos essenciais e práticas de trabalho interrompidos e não reativados com base em argumentos não assimilados por quem se vê em situação de abandono e negligência pelo ente público. As ações públicas direcionadas aos segmentos afetados revelam a sua perspectiva classista, ou seja, a que setores da cidade e frações sociais a atenção e proteção são efetivamente dispensadas - uma recorrência no caso brasileiro.

Eu reclamo hoje das estradas, né? Porque agora, com qualquer chuva, enche. Domingo agora encheu! Eu fiquei apavorada! Muita gente que veio pra igreja não pode voltar! Os que vieram visitar a família não puderam ir embora. Tem um monte de máquinas, mas tão paradas. Ponte que não tem. [...] já tem um ano e eles não fizeram nada! (Entrevistado 31 Bairro Santa Rita)

As perguntas são rápidas: "quando vamos ter o projeto do Rio Vieira?" Nós precisamos dessa informação pra que nós possamos plantar em volta do rio, recriar nossa mata no rio. E outra: as casas de Vieira, as pessoas de Vieira não querem sair de lá, querem continuar plantando, e nós precisamos saber como vai ficar a situação do $3^{\circ}$ distrito, dos agricultores do $3^{\circ}$ distrito. (Integrante da Avit - Audiência Pública 2)

O meu assunto é a creche Carinha de Anjo. Essa creche foi dada por uma ONG e, de 2 em 2 anos, troca o responsável. Agora eu estou lá. E o que aconteceu? Em janeiro aconteceu a tragédia também em Granjas Florestal e não sei porque a Defesa Civil, Emop, prefeitura não se interessaram em abrir a creche. São 44 crianças, a maioria vai lá mais pra se alimentar, vocês sabem que são crianças pobres. $A$ Emop diz que tem uma casa caindo lá no alto do morro. Nós já estamos há 10 meses com essa casa caindo. Eu gostaria que alguém pudesse responder. Sr. deputado, eu gostaria que o Sr. me desse uma resposta. Criança sem estudo, como é que vai ficar? Aí, não tem resposta, claro, né? (Participante da Audiência Pública 2)

É muito bonito ouvir o discurso das nossas autoridades, porque eles chegam e fazem uma síntese da nossa dificuldade, mas a gente tem olho. Olha só, falaram em 10 pontes, nós temos 54 pontes no nosso município. 0 trabalhador, o agricultor, pra ele transportar uma caixa de tomate ele tem que andar debaixo do rio, entrar dentro do rio pra encontrar uma estrada ali. Voltam novos discursos: não queremos discurso, queremos objetividade, uma resposta. (Sindicato da Indústria Têxtil - Audiência Pública 1)

Esse conjunto de enunciações destaca, de maneira direta, os elementos que constituem a experiência de abandono vivenciada: máquinas paradas, baixa mobilidade e o reconhecimento do tratamento que é dispensado aos afetados. 
Nas palavras de Zhouri (2010, p. 453), configura-se uma resistência legitimada pelo discurso dos moradores através do testemunho pautado na observação e na vivência, em contraponto ao posicionamento das autoridades e de suas retóricas denunciadas como "a síntese da nossa (sua) dificuldade". "[...] a gente tem olho!". "Não queremos discursos, queremos objetividade, uma resposta!".

\section{Considerações finais}

A moradia se revela elemento de fundamental importância para a reprodução social. $\mathrm{Na}$ experiência de muitos, esse bem só poderá ser acessado via autoconstrução e a partir de processos que envolverão a irregularidade na forma da apropriação da terra. Essa é uma realidade fortemente presente nas cidades da periferia do capitalismo, desencadeando cenários e simbologias que nos desafiam a compreensão. Uma das características que esse contexto permite identificar é que buscamos realçar neste artigo, qual seja, a relação de certos grupos com o espaço, revelando enraizamento e pertencimento, identidade, ainda que seja tecnicamente condenado ou pejorativamente traduzido pelas suas possíveis limitações e características de precariedade.

É relevante dizer que, antes de um território ser a "área de risco", tecnicamente classificada, ele representa o Lugar de viver e morar de certos sujeitos sociais, ou seja, representa a relação desse sujeito coletivo com o espaço. Isso nos remete a trajetórias de vida e a processos de vulnerabilização (Acselrad, 2006). Não se trata de dizer que o suposto "risco" que leva à condenação seja negado, mas, sim, ressignificado (Vargas, 2006) - isto é, são atribuídos novos sentidos ao ambiente periférico deteriorado a partir de muitos fatores. Territórios estrutural e ambientalmente degradados passam a ter a conotação de "espaços desejáveis" a partir da ausência de alternativas, e decorre daí a valorização de um patrimônio construído que se confronta e "supera" a noção técnica de risco, revelando-se como uma opção legítima (ou uma "oportunidade") diante da total falta de opção. Os vínculos de sociabilidade sobrepõem-se a partir de relações primárias, familiares ou comunitárias, que são traços culturais relevantes em tais grupos e, também, a partir da possibilidade de se contar com recursos adicionais para sua reprodução social, em contextos de ausência de políticas sociais efetivas de apoio à sua reprodução social.

0 Lugar representa, também, a expressão de uma luta pela permanência ante ameaça de desterritorialização pelo Estado. Entre outros fatores, isso se associa à necessidade da segurança da posse, da propriedade, ainda que ela se origine da "invasão dos locais disponíveis para os pobres", na expressão dos afetados (ibid.). A isso também se associam a insistência pelo retorno e reconstrução em locais tecnicamente condenados e a busca por alternativas individualizadas de minimização dos danos através de pequenas obras de reparo e recuperação da edificação, dos equipamentos, viabilizando, ainda que precariamente, a permanência. Na verdade, a ausência sistemática de uma rede de proteção social gera formas próprias de entendimento do mundo e práticas próprias de convivência com as ameaças.

Quando do desencadeamento do desastre, esses Lugares se projetam como objeto de contestação, o que só reforça a sua já condição 
de segregação e estigmatização: aquilo que Valencio e outros (2008) tratam como transposição da "área carente" para a "área de risco". É acionado o reconhecimento das fronteiras opositivas em relação a grupos sociais específicos e seus projetos de inserção no Lugar, na cidade, que são projetos antagônicos à noção da ordem social vigente. A enunciação originada no discurso oficial enseja a tentativa de anulação do Lugar calcada no discurso do risco. Porém, as estratégias discursivas, e não só elas, são mobilizadas também pelos grupos localizados e organizados em função da resistência - que se revela nesta pesquisa também como "resistência cotidiana" (Scott, 2002). Em Teresópolis/RJ, a experiência da Avit, em associação com outros movimentos regionais e nacionais, traduz-se como um esforço pela afirmação de direitos, num contraponto sensível às formas de gestão do desastre naquela região. Como afirma Zhouri (2010), a formação de mobilizações locais e a reconstrução do território (ou "a luta por", num esforço de revisão da agenda pública) colocam em pauta o esforço desses grupos em articular seu problema como um fato coletivo de onde emergem novas identidades políticas. Em oposição ao que se constata na atuação do Estado em face do desastre, a força desses significados traduz uma densidade por parte dos afetados (como bem explicitado em suas narrativas anteriormente registradas), que se contrapõe à ambivalência originada do comportamento da autoridade, porque é referendada pelo testemunho e pela vivência no Lugar. Tal autoridade é incisiva sobre a realidade, afirma-se antes os recursos e sobre o meio com a finalidade de ordená-lo, enquadrá-lo e se impor sem, no entanto, necessariamente entendê-lo. É ambivalente, pois, porque age sem a densidade que é correspondente aos Lugares que sofrem a intervenção, caindo em esvaziamento, violência, inadequação - desautorizando-se e deslegitimando diante do contexto e do seu próprio papel. 0 Lugar na discussão do desastre - em analogia a Zhouri (ibid.) quando de suas argumentações no debate ambiental - deixa de ser categoria residual, ganhando novos contornos, tonalidades, potencialidades, representando a inserção da diversidade e a heterogeneidade dos sujeitos, de suas formas de viver e morar, ante a imposição de verdades que querem se fazer únicas.

\section{Maria Auxiliadora Ramos Vargas}

Universidade Salgado de Oliveira, Curso de Serviço Social. Juiz de Fora, MG/Brasil. doravargas@uol.com.br 


\section{Notas}

(1) A categoria "Lugar" aparecerá no corpo do artigo com a inicial maiúscula, como um destaque que objetiva enfatizar e resguardar sua associação com a ideia de identidade e pertencimento.

(2) Este artigo resgata reflexões que integram a tese de doutorado "Da chuva atípica" à "falta de todo mundo": a luta pela classificação de um desastre no município de Teresópolis/RJ", disponível em www.bdtd.ufscar.br/htdocs/tedeSimplificado/tde_busca/arquivo.php?codArquivo=7786. A pesquisa foi desenvolvida no município de Teresópolis/RJ, no segundo semestre de 2011 e no mês de janeiro de 2012, envolvendo instituições diversas, a observação de 2 grandes audiências públicas e entrevista com moradores de 3 dos bairros Caleme, Campo Grande e Santa Rita, cujas narrativas, pelo teor do artigo, tiveram prioridade. Todos estavam envolvidos direta ou indiretamente no desastre desencadeado em janeiro de 2011 na Região Serrana do Rio de Janeiro.

(3) Reafirma-se a importância de serem consideradas as vulnerabilidades estruturais somadas àquelas que as mudanças climáticas possivelmente farão emergir e a necessária observação de outras variáveis implicadas no referido contexto.

(4) Reflexões sobre os atingidos por barragens no Vale do Jequitinhonha/MG.

(5) Vale ressaltar que os diferentes entrevistados mencionam que os territórios, nessa pesquisa considerados, não recebiam a classificação de "áreas de risco" até a ocorrência deflagrada em janeiro de 2011. Esse dado está respaldado pelo Mapeamento de Risco do município e incrementa o debate no que diz respeito à confiabilidade desses diagnósticos para a população e mesmo para alguns técnicos.

(6) Optou-se por manter, nos depoimentos deste artigo, as características da linguagem oral.

(7) Rosa $(2006$, p. 8) apresenta dados de pesquisa desenvolvida num assentamento precário de Teresópolis, enfatizando que a secundarização de fatores de ameaça se revela recorrente: “É interessante destacar dados de pesquisa realizada na Coreia, um dos assentamentos informais de Teresópolis, que ocupa parte da área do Parque Estadual do Três Picos, unidade de conservação cujos mananciais abastecem as Regiões Serrana e do Grande Rio. Quando os moradores foram perguntados sobre os principais problemas que enfrentam, na ordem de prioridade, o primeiro lugar ficou com a pavimentação. Somente em último lugar aparece a preocupação com os riscos físicos que os ocupantes sofrem devido à construção de suas casas em encostas íngremes e, muitas vezes, acima ou abaixo no nível das vias e servidões [...]".

(8) Foi recorrente a confirmação da informalidade como traço marcante, o acolhimento à pesquisa (em alguns casos sem agendamento prévio), o agrupamento espontâneo de pessoas num ímpeto de colaboração na produção das narrativas, sendo em suas próprias moradias ou em locais públicos, como a rua. O espaço público, o coletivo e o âmbito privado se mesclaram como possibilidade de abertura quase incondicional ao diálogo e ao relato tão "necessário" das versões diversas acerca do ocorrido, possibilitando a expressão da dor, do sofrimento, da solidariedade, assim como das diferentes interpretações da chamada "tragédia da Região Serrana". Cabe destacar que a demanda pela escuta foi algo marcante, ainda que passados 6 meses entre o nominado "impacto" e o início da pesquisa. Por essa razão, ou seja, pautadas na identificação de um grau de sofrimento e abandono explícitos, as narrativas deram-se com bastante fluidez, confirmando uma boa convergência entre as demandas dos grupos de moradores e a proposta da entrevista em profundidade, inclusive para a apreensão de elementos da subjetividade de tais grupos. 
(9) Referenciado na obra de Elias e Scotson (2000), que usam o termo para se reportarem àqueles estigmatizados por um grupo estabelecido, como pessoas de menor valor humano, carentes da virtude humana superior - o carisma grupal distintivo - que o grupo dominante atribui a si mesmo. "Os grupos mais poderosos [...] veem-se como pessoas 'melhores', dotadas de uma espécie de carisma grupal, de uma virtude específica que é compartilhada por todos os seus membros e que falta aos outros. Mais ainda [...], os indivíduos 'superiores' podem fazer com que os próprios indivíduos inferiores se sintam, eles mesmos, carentes de virtudes - julgando-se humanamente inferiores" (p. 20).

(10) Foi recorrente ouvir relatos informais de indivíduos residentes nos locais da pesquisa que nunca saíram de seus bairros para a região central da cidade.

\section{Referências}

ACSELRAD, H. (2006). Vulnerabilidade ambiental, processos e relações. Disponível em: http://www. fase.org.br/projetos/clientes/noar/UserFiles/17/Files/VulnerabilidadeAmbProcRelAcselrad.pdf. Acesso em: 28 dez 2011.

BACHELARD, G. (1998). A poética do espaço. São Paulo, Martins Fontes.

BOURDIEU, P. (2005). O poder simbólico. Rio de Janeiro, Bertrand Brasil.

CERTEAU, M. de (2009). A invenção do cotidiano: 1. Artes de Fazer. Petrópolis/RJ, Vozes.

ELIAS, N. e SCOTSON, J. L. (2000). Os estabelecidos e os outsiders: sociologia das relações de poder a partir de uma pequena comunidade. Rio de Janeiro, Jorge Zahar.

GALEANO, E. (2005). O livro dos abraços. Porto Alegre, L\&PM.

HAESBAERT, R. (2004). Dos múltiplos territórios à multiterritorialidade. Disponível em: http://www. uff.br/observatoriojovem/sites/default/files/documentos/CONFERENCE_Rogerio_HAESBAERT. pf. Acesso em: 22 ago 2012.

LEFEBVRE, H. (1991). O direito à cidade. São Paulo, Moraes. (2000). La production de l'espace. Paris, Anthropos.

MARTINS, J. de S. (2010). A sociabilidade do homem simples: cotidiano e história na modernidade anômala. São Paulo, Hucitec.

QUARANTELLI, E. L. (2005). “A social science research agenda for the disasters of the 21 st century: theoretical, methodological and empirical issues and their professional implementation". In: PERRY, R. W. e QUARANTELLI, E. L. (eds). What is a Disaster? New answers to old questions. USA, International Research Committee on Disasters.

ROSA, W. M. (2006). Regularização fundiária e eficácia dos novos instrumentos: a concessão de uso especial para fins de moradia no município de Teresópolis-RJ. Disponível em: http://www.ibdu. org.br/imagens/Regularizacaofundiariaeeficacia dos novos instrumentos.pdf. Acesso em: 15 set 2012.

SCOTT, J. (2002). Formas cotidianas de resistência camponesa. Campina Grande, Raízes. 
VALENCIO, N. et al. (2008). "Após o desastre: abrigos temporários como loci de reafirmação da vulnerabilidade dos afetados pelas chuvas". In: REUNIÃO BRASILEIRA DE ANTROPOLOGIA. Anais. Porto Seguro, ABA.

VALENCIO, N. (2010). "O desastre como locus da barbárie: apontamentos sobre o caso brasileiro". In: VALENCIO, N. (org.). Sociologia dos desastres: construção, interfaces e perspectivas no Brasil. São Carlos, RiMa.

(2012). Para além do dia do desastre - o caso brasileiro. Curitiba, Appris.

(2014). "Dos desastres recorrentes aos desastres à espreita". In: ZHOURI, A. e VALENCIO, N. (orgs.). Formas de matar, de morrer e de resistir: limites da resolução negociada de conflitos ambientais. Belo Horizonte, Editora UFMG.

VARgAS, M. A. R. (2006). Construção Social da Moradia de Risco: trajetórias de despossessão e resistência - a experiência de Juiz de Fora/MG. Dissertação de Mestrado. Rio de Janeiro, IPPUR/ UFRJ.

(2013). Da "chuva atípica" à "falta de todo mundo": a luta pela classificação de um desastre no município de Teresópolis/RJ. Tese de Doutorado. São Carlos, Universidade Federal de São Carlos.

ZHOURI, A. e KLEMENS, L. (orgs.) (2010). Desenvolvimento e conflitos ambientais. Belo Horizonte, Editora UFMG.

Texto recebido em 30/set/2015

Texto aprovado em 31/mar/2016 
